\title{
Xenia: Refugees, Displaced Persons and Reciprocity
}

\author{
JOHN HARRIS
}

What has happened to our culture today that strangers to our shores are not welcomed, not given the protection of our laws, and the warmth of our hospitality? What has happened to civilization? Refugees, displaced persons and desperate would-be migrants are treated as creatures of no consequence, no interests, and no rights. Britain-a nation built on migration: Celts, Saxons, Romans, Danes, Normans, Huguenots, Jews, West Indians, Asians from India, Pakistan, Ceylon (Sri Lanka) Singapore, and so many others-has turned its back on contemporary strangers and on ancient values. To understand this tragedy and both the origins and possible solutions to its disastrous effects, we need to start in the bronze age, nearly three thousand years ago, with one of the most complex and human of humans ever imagined, Odysseus of Ithaca.

Explaining the Homeric concept of xenia ${ }^{1}$ (hospitality) Emily Wilson, ${ }^{2}$ the first woman translator of the Odyssey, notes recently in the introduction to her wonderful translation, that:

\begin{abstract}
Before approaching the island of the Cyclopes, Odysseus tells his men that he has to find out ... whether the inhabitants are "lawless aggressors," or people who welcome strangers...the willingness to welcome strangers is figured enough, in itself, to guarantee that a person or culture can be counted as law-abiding and 'civilized.' ${ }^{3}$
\end{abstract}

With refugees from war, famine, and persecution arriving in increasing numbers in Western Europe, especially from the Mediterranean, Homer's "wine dark sea," we, more than ever, need to revive some version of xenia if we are ourselves to remain even half-way decent and 'civilized.'

I am of course not unaware that much has indeed happened in the nearly 3000 years since the probable dates for Homer(s); nor am I deluded that all was 'hunky-

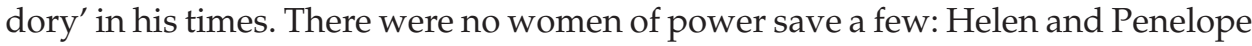
among them, and miscellaneous goddesses of course; slaves were abundant in the 'best homes,' 'sacking cities' (murdering the men and enslaving the women and children) was more than a pastime; indeed for Odysseus and his ilk, it was a way of life. But with all his complex vices and virtues, Odysseus was on to something that, in his best moments, comes automatically ${ }^{5}$ to him.

Xenia embodies a number of ideas, and important from a theoretical perspective is what these days is sometimes called 'the rule of rescue.' This suggests that those in need of protection, because they are drowning, literally or figuratively; because they need food, shelter, care, medicine, comfort, or protection, are absolutely entitled to that rescue, if it is humanly, or even supernaturally, possible to deliver it. This is why all civilized societies maintain rescue services (whether financed privately or publicly) from the basics: fire, police, ambulance, and defense, to healthcare, social services, and education (schools, universities, libraries, art galleries, theatres and museums). ${ }^{6}$ It is also 
why all of these civil institutions are governed by the principle of equality: that each person is entitled to the same concern, respect and protection as is accorded to any. Homer's observation that populations divide between "lawless aggressors," or people who welcome strangers, and that only the latter are truly 'civilized' is the basis of all morality and hence, of civilization itself.

Another important element of xenia is the opportunity to do good and to learn from two of the most powerful imperatives known to humankind: the imperatives of respect for (morality toward), and curiosity about, everything-in this case strangers and about what they can contribute.

Here we focus on 'strangers': displaced persons, refugees and immigrants. People have always prioritized kinship bonds-friends and family, tribe and clan, fellow citizens, ${ }^{7}$ often with disastrous effects, on both morality and logic. I have insisted (since my early teens) ${ }^{8}$ that such bonds are always irrelevant and often disastrous: morally, socially and politically. The task is always to understand why and with what scope and limits, individuals and groups are entitled to, and need, concern, respect, and protection. ${ }^{9}$ The relevant question, following the late great John Locke, is always: "is this individual a person," regardless of what I call "the usual suspects?": race, creed, color, nationality, political affiliation species, etc., and, whether that person is human, or another species of person, animal, vegetable or mineral-Metal Mickey, flesh and blood, silica, or whatever.

The moral leap, made so many centuries BCE, and of which we, shamefully, need to remind ourselves today, is the extension to strangers wherever they are from (including Mars, Venus, or the lab down the road), and of whatever they are made. And especially of course when they are familiar sorts of persons unproblematically recognizable as human beings; but simply displaced human persons, or human migrants or refugees. I say "especially" here, not because human persons are more valuable-necessarily have more rights and interests etc., than others-but simply because we have no excuses for not immediately attributing to them our own moral status. ${ }^{10}$ In this essay I concentrate on displacement from, and migration across, national boundaries as a particular application of a much more general and comprehensive problem.

Emily Wilson ends the "Translators Note" to her version of the Odyssey ${ }^{11}$ with these words, inviting us maybe, to act likewise, or perhaps just to "listen to"12 her translation of his story:

There is a stranger outside your house. He is old, ragged and dirty. He is tired. He has been wandering, homeless, for a long time, perhaps many years. Invite him inside. You do not know his name. He may be a thief. He may be a murderer. He may be a god. He may remind you of your husband, your father or yourself. Do not ask questions. Wait. Let him sit on a comfortable chair and warm himself beside your fire. Bring him some food, the best you have, and a cup of wine. Let him eat and drink until he is satisfied. Be patient. When he is finished he will tell his story. Listen carefully. It may not be as you expect.

Wilson is here perhaps as much inviting us to read on, as she is making a recommendation as to how to treat a stranger we think just might be a murderer. But as a parable about our relationship with strangers on our doorstep, it generates some of the best food for thought available. 
What might give us pause with Wilson's invitation, is the prospect that the stranger at the gate might not, after all, be Odysseus with a wonderful story to tell; but a murderer, or indeed might be Odysseus himself, but in his "sacker of cities" mood. ${ }^{13}$ Can we be rationally prudent and still decent and hospitable?

\section{Our Duties to One Another}

Recently, I rehearsed ${ }^{14}$ what I believe to be the moral basis for our obligations to other persons via the obligations of any state to all within its borders. An issue for us all, sharpened by consideration of the concept of xenia, is the extent to which this is a more global or even universal obligation. My answer is and has always been ${ }^{15}$ that morality is universal. However, in this essay, I concentrate on the obligations of the people and governments of one nation to the citizens of others or to those displaced persons who have no established citizenship. In this context (and bearing in mind the resurgence of a petty nationalism globally), the obligations we may owe to one another seem sometimes overwhelming. How can we meet all the needs that we know of wherever they exist?

\section{The Safety of the People}

For convenience, and so as not to frighten the horses, ${ }^{16}$ we start at home, with the state (our state), the state for which all citizens share democratic responsibility. Although morality knows no frontiers, for practical purposes, if we are genuinely interested in ameliorating the lot of displaced persons we need to start where the action takes place, at the border where what happens is controlled by the states whose border it is.

The state, surely, has responsibility for the safety of the people. ${ }^{17}$ But which people? Citizens only, or also residents; visitors at home, or also citizens abroad? And what about refugees and displaced persons at our gates?

The idea that individual responsibilities of one to another are often most efficiently and cost effectively discharged for us collectively by the state, is evidenced in many different ways. In the first place, nation states characteristically accept this responsibility, and indeed, often assert it. Second, it is clearly a dimension of the principle of equality, a principle to which almost no state can now profess indifference. This principle is, I believe, a central clause in what is often called 'the social contract,' whether expressly stipulated or rationally implied.

Not only has the idea of a social contract been expressed or implied as the best way of characterizing the arrangements whereby governments (be they a sovereign or an assembly) acquire legitimacy as governors from the consent of the people. Such arrangements also deliver the reasons whereby the citizens acquire obligations to the government and to their fellow citizens: to obey the law and the appropriate and legal directions of legitimately-appointed officials. All these reasons are moral reasons, not contractual ones. The consent of the people is given to secure their rights and interests, in short, the moral objectives of the people.

\section{The Social Contract}

If we reflect on what people want and need in the way of protection and think also about the role of the modern state and its obligations to protect and defend all those 


\section{John Harris}

within its borders, I believe we will find that the most significant threats to life and liberty, except in exceptional circumstances, come not from the threat of armed aggression from without, although this remains a significant risk, but particularly from a combination of health and welfare needs within. For most citizens, threats to their lives and curtailment of liberty arise from poverty, illness, and accident. Poverty is perhaps the single most reliable predictor of misery, suffering, illness, and premature death in most societies. ${ }^{18}$

In 1651, Thomas Hobbes delivered perhaps the most compelling statement of the idea of a social contract ${ }^{19}$ :

The office of the sovereign, be it a monarch or an assembly, consisteth in the end for which he was trusted with the sovereign power, namely the procuration of the safety of the people; to which he is obliged by the law of nature, ... But by safety here, is not meant a bare preservation, but also all other contentments of life, which every man by lawful industry, without danger, or hurt to the commonwealth, shall acquire to himself.

And this is intended should be done, not by care applied to individuals, further than their protection from injuries, when they shall complain; but by a general providence, contained in public instruction, both of doctrine and example; and in the making and executing of good laws, to which individual persons may apply their own cases.

It is clear that Hobbes is prepared to interpret the idea of the safety of the people very widely and in an egalitarian spirit. He was famously preoccupied with violence and physical danger, but when such dangers are less pressing, he is prepared to reflect more widely on the concept of public safety. Later in the same chapter Hobbes makes clear that "the safety of the people":

Requireth further from him, or them that hath the sovereign power, that justice be equally administered to all degrees of people; that is, that as well the rich and mighty, as poor and obscure persons, may be righted of the injuries done them;..."20

He also allows that people who are the victims of inevitable accident be provided for by the state:

And whereas many men, by accident inevitable, become unable to maintain themselves by their labour; they ought not to be left to the charity of private persons; but to be provided for, as far forth as the necessities of nature require, by the laws of the commonwealth. ${ }^{21}$

The social contract, by which liberty is surrendered in exchange for protection, and obedience granted to the sovereign in exchange for legal guarantees of safety, has two essential features that bear stressing. Immigrants and displaced persons, by placing themselves within a jurisdiction, and in a sense 'asking' for sanctuary, accept the sovereign power of their place of refuge. Acceptance of the sovereign power confers a moral right to many of the privileges of citizenship; just how many, and to what degree, is part of the argument of this paper. 
Any state which denies protections required for the safety of any of its people effectively places those people beyond the pale, not only of its moral concern, but literally beyond the ambit of its legitimate control. It makes of them 'outlaws,' people neither protected nor bound by the law. We and other states expect and require immigrants and visitors alike to respect our laws, and, to some extent, our customs. We in our turn may not deny them its protections.

\section{State Acceptance of Responsibility for the Safety of the People and the Principle of Equality}

That all contemporary nation states do-as a matter of fact and as a clearlyexpressed ${ }^{22}$ principle-accept responsibility for the safety of their people is manifest in many ways. States are classically defined in terms of their capacity to assert authority over their population and defend that population, at least within their borders. A major purpose and point of an ability to defend borders is of course to protect citizens and other inhabitants from foreign invasion, but the extent of the obligation to secure the safety of the people is obviously wider than that, as we shall now see.

Perhaps, the clearest contemporary manifestation of state responsibility for the protection of the people is in responsibility for the principal emergency services: fire, police, ambulance, other health care and defense forces. All these are directly concerned with the safety of the people. Although it is only defense forces that are almost universally also maintained entirely at public expense, all these services are the responsibility of the state; and, if they were not maintained by some means or other, the state would be shirking its responsibilities. Health for example, is usually the responsibility of a senior minister of state. Who pays is not the issue; that the services are provided, is. ${ }^{23}$

What would we make of a state that provided none of these services? Not only is it scarcely imaginable at all, it would be difficult to see how it could function as a unified state. So that when a state institutes immunization programs against infectious childhood diseases, when it provides safe drinking water, when it makes laws about speed limits on roads, or wearing of seatbelts in cars, or when it licenses or does not license firearms, or slaughters infected cattle, when it mobilizes national resources to fight forest fires, or to build flood defenses, when it evacuates towns in the path of a hurricane, or when a post mortem examination is ordered by the courts to explain a mysterious death, responsibility for the safety of the people is recognized, acknowledged, and asserted.

Now of course I have spoken of a state doing this or that, when many of these things are done by local government, the courts, or other agencies, including, of course, private agencies. The point is that if any of these things were not done, it would be the state's responsibility to find out why, and to make sure that they were done in future.

Finally, collective responsibility for rescue is entailed by any competent interpretation of one of the most widely accepted moral rules, the rule of rescue. ${ }^{24,25}$

I have tried to sketch here a, by no means new, moral and philosophical basis for xenia, for the urgency and importance of measures to protect the lives and liberty, not only of citizens, but of all people within a particular jurisdiction, however they came to be there, and to set it in historical and theoretical context. 
This brings into sharp focus the fact that our individual obligations and responsibilities to one another as persons are often most cost effectively and indeed most effectively delivered, all things considered, by collective action. ${ }^{26}$

\title{
The Xenia of Homer
}

Returning at last specifically to xenia and the issue of our obligations to strangers, refugees and displaced persons, I believe we can see a way to apply Homeric values to our contemporary situation. Odysseus, after all, and acting as the de jure and de facto leader of his men, is seeking to deliver the shelter, respite, and protection he and his band need after so many vicissitudes.

Hobbes is eloquent, and to me persuasive, on the mutual obligations of citizens and others within a particular jurisdiction, and their relation to the sovereign power. But how, if at all, does xenia help us to think about the state's obligations to admit new residents, even temporarily, into the body politic?

Consider again Wilson's suggestion to welcome strangers, and the prospect that the stranger at the gate might either not be Odysseus with a wonderful story to tell after all, but a murderer. The recent case of a homeless man who murdered the woman who gave him a home and also her son, is a perhaps isolated but none-theless cautionary tale that provides additional moral reasons to discharge the duty of xenia collectively rather than individually in many cases. ${ }^{27}$

\begin{abstract}
A homeless man who turned on the woman who tried to help him and killed her and her teenage son has been jailed for life with a minimum term of 30 years... Aaron Barley stabbed Tracey Wilkinson 17 times and inflicted eight knife wounds on her son, Pierce, after sneaking into their home in Stourbridge, West Midlands, dressed in a balaclava...Barley, who was given food, friendship and shelter by the family, also tried to kill Wilkinson's husband, Peter, when he returned home after walking the dog. ${ }^{28}$
\end{abstract}

If we consider the nature of the duty to invite the stranger in: but not necessarily into our home, our private space, but into our society to share its social welfare, healthcare and other collective protections, that duty would be both safer for all and more manageable. Such consideration would have to be serious and proportional to the wealth and capacity of our/any society to deliver. This could also be maximized, for example, by realistic attempts to achieve burden sharing in this regard internationally.

What is required however is some serious work toward the social and institutional mechanisms required to achieve this goal. One way of moving in this direction may be a rethink of how we, in the rich nations, can stop being, in Homer's words, "lawless aggressors" toward those who land on our shores or seek refuge with us. How can we become the sorts of people who welcome strangers? ${ }^{29}$

\section{Xenia is not Only Right; it is in Our Own Prudential Interests}

As Homer himself observed, xenia is also in our own prudential interests. In the Odyssey, King Menelaus reacts angrily to a servant who would send strangers away without food, shelter and assistance: 
We two were fed by many different hosts Before returning home. As we may hope

For Zeus to keep us safe in future times, 30

In book 9 of The Odyssey (lines 172-6). Approaching the island of the Cyclopes, Odysseus, as noted above, addresses his men. Here is the full text:

\author{
My loyal friends! Stay here, the rest of you, \\ While with my boat and crew I go to check \\ Who those men are, find out if they are wild \\ lawless aggressors, or the type to welcome \\ strangers, and fear the gods.
}

If, as I have argued above, and as Hobbes maintained, the social contract is based on the desire of people to secure their safety, broadly conceived, by trading obedience for protection, why should not this be extended to outsiders who arrive, 'at the gates,' so to speak, to claim admittance? It is Homer who provides the answer.

As I suggested earlier, it is not the social contract that creates our obligations, it is rather our obligations to one another that create the contract. And our obligations are to one another as persons. The fundamental rights and obligations that the social contract expresses and secures preexist any 'contract,' they are not established by it. They are possessed by all persons, not just by fellow citizens or fellow countrymen and women. ${ }^{31}$ Extending these rights and recognizing these interests in displaced persons and refugees, is not only required because they are persons - the sorts of creatures who like us have rights and interests, but because it is the right thing to do, the moral thing to do. It is also, as Homer saw, because it is in our prudential interests so to do.

\title{
Widespread and Spontaneous Xenia.
}

Eric Newby and Iris Origo, through very different experiences, describe the quite literally valiant hospitality demonstrated by ordinary Italians, mostly 'contandine' (peasants or country people) to escaping Allied servicemen and to refugees in Italy in World War II, and at great personal risk. These accounts give further eloquent eye-witness testimony to both the heroism of those who practice xenia and to the prudence of such an ethic. ${ }^{32}$ Newby and Origo also demonstrate that xenia can be, and has been, practiced on a very wide scale, by literally tens of thousands of people, for the benefit of many thousands more with only minimal co-ordination and without collective purpose.

Perhaps it was with Menelaus in mind (or perhaps Menelaus with the help of the Gods was anticipating another European conflict?) that Eric Newby wrote this in his Preface to his autobiographical book: Love and War in the Apennines. ${ }^{33}$

I finally decided to write this book because I felt that comparatively little had been written about the ordinary Italian people who helped prisoners of war at great personal risk and without thought of personal gain, purely out of kindness of heart. 
Iris Origo gives similar personal testimony:

Of the 70,000 Allied p.o.w.s at large in Italy on September $8^{\text {th }} 1943$, nearly half escaped, either crossing the frontier to Switzerland or France, or eventually rejoining their own troops in Italy; and each one of these escapes implies the complicity of a long chain of humble, courageous helpers throughout the length of the country. "I can only say" wrote General O'Connor to me, "that the Italian peasants and others behind the line were magnificent. They could not have done more for us. They hid us, gave us money, clothes and food-all the time taking tremendous risks... We English owe a great debt of gratitude to those Italians whose help alone made it possible for us to live, and finally to escape..."

And Origo, who herself helped, directly or indirectly, probably many hundreds of Allied soldiers and refugees, concludes:

For a short time all men returned to the most primitive traditions of ungrudging hospitality, uncalculating brotherhood. At most, some old peasant-woman, whose son was a prisoner in a far-away camp in India or Australia, might say - as she prepared a bowl of soup or made the bed for a foreigner in her house - 'Perhaps someone will do the same for my boy'. ${ }^{34}$

I hope I have demonstrated that, as Origo says, these traditions are indeed primitive, but also very ancient, long lived and well justified, morally and prudentially. Moreover, Newby's and Origo's accounts confirm that xenia can spontaneously (but not without deliberation) operate on a vast scale, voluntarily practiced by what must have been countless thousands of Italians and others throughout Europe, for the benefit of thousands of strangers and at great personal risk to themselves. The scale of this and other such acts demonstrates that support, for the plight of, and care for, strangers, for xenia, runs deep, and that is not fanciful to suppose that it might be recognized and even accepted today, both for moral and for prudential reasons.

We should not forget that we never know when we might need, and desperately hope for, someone to do the same for a foreigner in her house, a stranger who just happens to be our boy or girl.

\section{Notes}

1. I am very much indebted to my friend Gabrielle Rifkind, with whom I worked as co-author on another article on the concept of xenia, with a rather different orientation to this one. Gabrielle's insights, ideas, originality and enthusiasm have greatly influenced me and this discussion of xenia and displaced persons. I am also deeply indebted to Silvia Camporesi, John Coggon, and Tomi Kushner for detailed comments and suggestions and for moral support. I acknowledge that I have freely drawn on other recent work of my own, particularly on my book How to be Good. Oxford: Oxford University Press; 2106. When I remember where my ideas have come from I have scrupulously tried to reference these places individually in what follows. But as Maria says in Shakespeare's Twelfth Night: "thought is free" (and she might have added "free ranging") and not all of it, regrettably perhaps, frequents the 'buttery bar' of recollection. Shakespeare W. Twelfth Night Act 1. Scene 3. Line 67. In: Proudfoot R., Thompson A, Kastan DS, eds. The Arden Shakespeare. Walton-OnThames: Thomas Nelson and Sons Ltd.;1998, at 1192.

2. Wilson E, trans. The Odyssey. London: W.W. Norton and Company Ltd; 2018, at 23.

3. See note 2 , Wilson 2018 , at 245 , lines $172 \mathrm{ff}$.

4. I write of Europe as a European and as the grandson (and remoter descendant) of immigrants but analogous issues and their stories occur everywhere. 
5. I do not however put any argumentative weight on the word automatic, which I discuss at length in my book How to be Good. Oxford: Oxford University Press; 2016.

6. I was fortunate to have had the opportunity to rescue myself from profound ignorance and poor education thanks to the availability of free museums and galleries and a subsidized theatre, in the England of the '60s. See Harris J. The Accidental Professor. Cambridge Quarterly of Healthcare Ethics 2017;26(1):1-9.

7. Here again, I am indebted to Gabrielle Rifkind.

8. Harris J. Thought and Memory. Coggon J, Holm S, Chan S, Kushner T, eds. From Reason to Practice in Bioethics: An Anthology Dedicated to the Works of John Harris. Manchester: Manchester University Press; 2015 at $16-30$.

9. See Harris J. Violence and Responsibility. London, Boston and Henley: Routledge \& Kegan Paul; 1980; Harris J. The Value of Life. London: Routledge; 1985.

10. Unless, of course, we have special reasons for doubting their personhood in particular cases. See note 9, Harris 1985.

11. See note 2 , Wilson 2018 , at 91 .

12. I use the words "listen to" advisedly, in connection with a text that I have only "listened to" in my head as I read her beautifully crafted and rhythmic iambic pentameter-Shakespeare's meter!

13. See note 2, Wilson 2018, at 9.263-6.

14. Harris J. How to be Good. Oxford: Oxford University Press; 2016.

15. See note 9, Harris1980 and 1985.

16. Echoing a remark reliably attributed to Mrs Patrick Campbell; available at https://en.wikiquote. org/wiki/Mrs_Patrick_Campbell (last accessed 22 Jan 2019).

17. In this section, the argument follows lines I developed in detail in Chapter 11 of How to be Good. See note 14 , at $172-85$.

18. And where all cannot be rescued, justice requires at least an equal opportunity of rescue, the meaning of which is of course the subject of this paper.

19. Hobbes T. Leviathan from Oakshott M, ed. Oxford: Basil Blackwell; 1960. Part II. Chapter 30, at 219. (First published 1651.)

20. See note 19, Oakshott 1960, Part II.

21. See note 19, Oakshott 1960, Part II.

22. By deeds more often than by words.

23. By extension, education is also a service in part required to secure the safety of the people.

24. It is implied by two other widely accepted moral principles, namely the principle of beneficence and the principle of nonmaleficence. These are implied by the principle of equality, and so do not need further articulation.

25. We are, in short, concerned with the following sorts of questions: Does the nation state have a function? Does it have a job to do? Does it have moral responsibilities as well as powers and prerogatives? Much modern moral theorizing about these questions has concerned itself with the scope and limits of this power in one form or another. Theories about the minimal state for example, or about rights, are concerned with limitations on state power, with the rights and responsibilities of citizens. (See Nozick R. Anarchy State \& Utopia. Oxford: Basil Blackwell; 1974. Ackerman B. Social Justice in the Liberal State. New Haven: Yale University Press; 1980, and Dworkin R. Taking Rights Seriously London: Duckworth; 1977. Suppose a state keeps defense forces... what are they for? For what should they be used? Can anything be deduced from their existence and deployment? What is the rule of rescue? Who should obey the rule and when?

26. For a more complete defense of these ideas see note 14, Harris 2016.

27. https: / / www.theguardian.com/uk-news / 2017/oct/04/aaron-barley-homeless-man-whomurdered-woman-who-helped-him (last accessed 13 Apr 2018).

28. See note 27.

29. I am indebted to Katrien Devolder for valuable suggestions here.

30. See note 2, Wilson 2018, Book 4, at 27-34 and 153.

31. I argue for the moral value and equality of all persons in my book The Value of Life. See note 9, Harris 1985.

32. See Newby E. Love and War in the Apennines. London: Picador;1983, and Origo I. War in the Val d'Orcia. London: Allison and Busby; 1999.

33. See note 32, Newby 1983.

34. See note 32 , Origo 1999, at 23-4. 


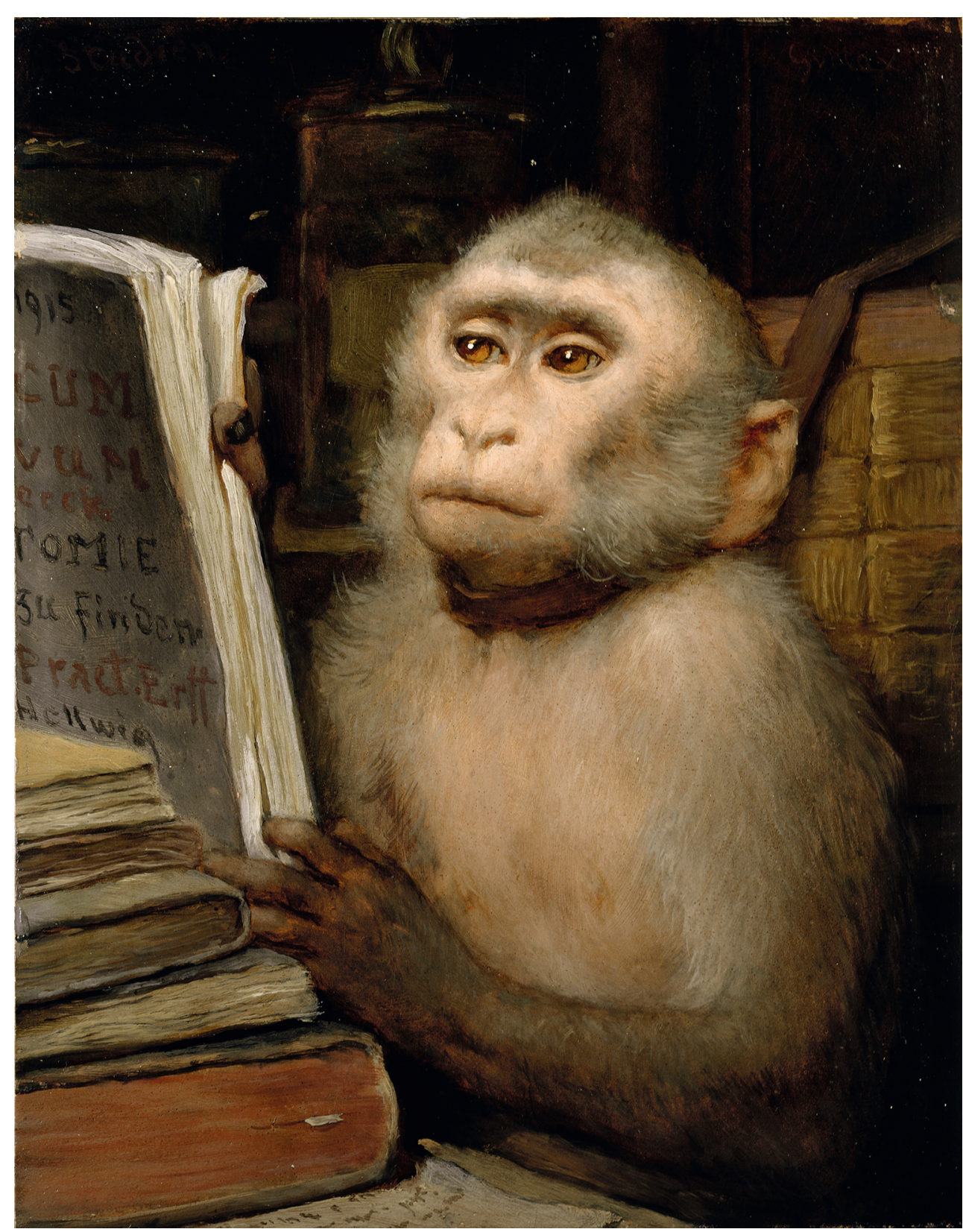

Gabriel Cornelius von Max (1840-1915), Reading Ape (1915). Photo Credit: bpk Bildagentur Location: Museum Georg Schafar, Schweinfurth, Germany/ Art Resource, NY. Reproduced by permission. 